Aesthetics of Gentrification 


\section{Cities and Cultures}

Cities and Cultures is an interdisciplinary book series addressing the interrelations between cities and the cultures they produce. The series takes a special interest in the impact of globalization on urban space and cultural production, but remains concerned with all forms of cultural expression and transformation associated with modern and contemporary cities.

\section{Series Editor:}

Christoph Lindner, University College London

Advisory Board:

Ackbar Abbas, University of California, Irvine

Myria Georgiou, London School of Economics and Political Science

Derek Gregory, University of British Colombia

Mona Harb, American University of Beirut

Stephanie Hemelryk Donald, University of Lincoln

Shirley Jordan, Queen Mary, University of London

Nicole Kalms, Monash University

Geofffrey Kantaris, University of Cambrigde

Brandi Thompson Summers, University of California, Berkeley

Ginette Verstraete, VU University Amsterdam

Richard J. Williams, University of Edinburgh 


\section{Aesthetics of Gentrification}

Seductive Spaces and Exclusive Communities

in the Neoliberal City

Edited by

Christoph Lindner and

Gerard F. Sandoval 
Cover illustration: Oliver Wainwright

Cover design: Coördesign, Leiden

Lay-out: Crius Group, Hulshout

$\begin{array}{ll}\text { ISBN } & 9789463722032 \\ \text { e-ISBN } & 9789048551170 \\ \text { DOI } & 10.5117 / 978946372203^{2} \\ \text { NUR } & 75^{8}\end{array}$

\section{(c) $(1) \Theta \Theta$}

Creative Commons License CC BY NC ND

(http://creativecommons.org/licenses/by-nc-nd/3.o)

@ All authors / Amsterdam University Press B.V., Amsterdam 2021

Some rights reserved. Without limiting the rights under copyright reserved above, any part of this book may be reproduced, stored in or introduced into a retrieval system, or transmitted, in any form or by any means (electronic, mechanical, photocopying, recording or otherwise).

Every effort has been made to obtain permission to use all copyrighted illustrations reproduced in this book. Nonetheless, whosoever believes to have rights to this material is advised to contact the publisher. 